\title{
Influence of Human Disturbance to the Small Mammal Communities in the Forests
}

\author{
Xingyuan Men"1*\#, Xianguo Guo ${ }^{2 *}$, Wenge Dong2, Nan Ding1, Tijun Qian² \\ ${ }^{1}$ Department of Plant Protection, Shandong Academy of Agricultural Sciences, Jinan, China \\ ${ }^{2}$ Laboratory of Vector \& Pathogen, Dali College, Dali, China \\ Email: ${ }^{\#}$ Menxy2000@hotmail.com
}

Received 19 September 2014; revised 26 October 2014; accepted 11 November 2014

Academic Editor: Syed Moazzam Nizami, Arid Agriculture University, Pakistan

Copyright (C) 2015 by authors and Scientific Research Publishing Inc.

This work is licensed under the Creative Commons Attribution International License (CC BY). http://creativecommons.org/licenses/by/4.0/

(c) () Op Open Access

\section{Abstract}

Small mammals have been proposed playing an important role in the energy flow and regeneration of forest ecosystems. We compared species richness, diversity $\left(\mathrm{H}^{\prime}\right)$ of small mammal communities and abundance of six dominant species of small mammals in disturbed and protected forests (four age classes: 6 - 10, 11 - 15, 16 - 20 and 31 - 40 years old) in China. We also investigated the structural variables (such as species richness, cover rate and abundance of shrubs and grasses) in the bottom layer, which considered to be important for small mammals and might be altered by human disturbance. The relationships between small mammals and these structural variables were examined to determine the potential effects of human disturbance on the small mammals in the restored forests. Our results indicated that the structure and composition of the vegetation in the bottom layer were simplified by human disturbance, while the abundance and cover rate of grasses were significantly increased. Although no significant differences were observed in species richness of small mammals between the protected and disturbed forests at the same age, the diversity index of small mammals in the protected forests was always significantly higher than in the disturbed forests. Regression showed that the species richness and diversity of small mammals increased with the species richness of shrubs, and was negatively correlated to the cover rate of grasses in the bottom layer. Human disturbance increased the total abundance of small mammals, and the increased cover rate of grasses in the bottom layer was beneficial to the abundance of small mammals. Obvious succession of small mammal communities occurred as the protected forest aged. In the protected forests, small ground-dwelling mammals $(A$. chevrieri, $E$. miletus and M. pahari) were the dominant species in the younger forests. Other mammals (T. belangeri, $D$. pernyi and $C$. erythraeus) gradually became the dominant species as the protected forests aged. However, in the disturbed forests, the smaller ground-dwelling mammals (T. belangeri, D. pernyi and C. erythraeus) were always the dominant species at all ages of the disturbed forests.

"The first two authors contributed equally to this work.

"Corresponding author. 
Regression indicated that the cover rate of grasses in the bottom layer was beneficial to the three smaller body size and ground-dwelling small mammal species, while the shrubs were beneficial to the three bigger body size mammal species.

\section{Keywords}

\section{Forest Restoration, Human Disturbance, Small Mammals, Structural Variables}

\section{Introduction}

A large area of forest has been restored following excessive deforestation in the 1960s and 1970s in China. For example, excessive cutting decreased forests cover from 47\% to about 25\% in Yunnan Province; through forest restoration, the cover rate has reached about $50 \%$ now. These restored forests can be divided into two classes: protected forests and disturbed forests. Protected forests are situated mostly in the natural reserve, and damage to vegetation is forbidden in these areas. Cutting of trees is also forbidden in the disturbed forests, and the main disturbance in these forests is cattle and goat grazing.

A worldwide standard is to base forest management on the values related to biodiversity and sustainability of ecosystems (Folke et al., 1996; Costanza et al., 2000). Small mammals have been proposed as indicators of sustainability in forests (Carey \& Harrington, 2001; Pearce \& Venier, 2005), because they constitute a considerable resource for many mammalian and avian predators (Krebs \& Myers, 1974; Hörnfeldt et al., 1990; Carey \& Johnson, 1995), and consume plants, lichens, fungi and invertebrates (Buckner, 1966; Ericson, 1977; Ure \& Master, 1982; Gebczynska, 1983; Hansson, 1988; Carey et al., 1999; Wells et al., 2009), which makes them important in the energy flow of forest ecosystems. Some small mammals also play a significant role in the seedling establishment and regeneration of forests by spreading seeds of trees (Vander Wall, 1995 \& 1997; Briggs, 2009).

Many studies have examined the small mammals in forests (Saitoh \& Nakatsu, 1997, Mengak et al., 1989; Sullivan et al., 2000) and investigated their biodiversity (Dueser \& Shugart, 1979; Kelt, 2000; Plumpter, 2000; Sullivan \& Sullivan, 2001; Niedziałlkowska et al., 2010) and relationships with forest habitats (Dueser \& Shugart, 1978; Yahner, 1986; Bowman et al., 2000; Carey \& Harrington, 2001; Ecke et al., 2002; Mengak \& Guynn, 2003; McCay \& Komoroski, 2004; Men et al., 2006; Manning \& Edge, 2008). Some of these studies suggested grasses in the bottom layer of forests were important in providing food and shelter for small mammals (Bowman et al., 2000; Niedziałlkowska et al., 2010). However, little is known regarding the effects of human disturbance to the bottom layer on small mammals in the forest.

In this paper two types of restored forests, namely protected forests and disturbed forests, at four age classes (6 - 10, 11 - 15, 16 - 20 and 31 - 40 years old) were comparatively studied in Yunnan Province, where about 60\% of the mammal species of China occur, although its area is only $4.1 \%$ of the total national area (Liu et al., 2003). We investigated the structural variables in the bottom layer that may be altered by human disturbance. Community characteristics and populations of small mammals were also compared between the two forest types, with particular attention to the correlation between the structure variables of forests and small mammals.

\section{Methods}

\subsection{Study Sites}

Studies were carried out in February to April in 2004 on the southern slopes $\left(99^{\circ} 58^{\prime} \mathrm{E}-100^{\circ} 27^{\prime} \mathrm{E}, 25^{\circ} 25^{\prime} \mathrm{N}\right.$ $25^{\circ} 58^{\prime} \mathrm{N}$ ) of Mt. Yunling, in the west of Yunnan Province of China. The height above sea level is $1950-2050 \mathrm{~m}$. Average annual temperature and precipitation were 15.1 degrees centigrade and $110 \mathrm{~cm}$, respectively.

Protected forests were located in the Cangshan Mountain and Erhai Lake National Reserve. The vegetations were not disturbed by human beings and in nature protection area. Disturbed forests were near the national reserve. These forests were all plantations primarily composed of Yunnan pine (Pinus yunnanensis) (92\% of all trees), and Armandi pine (Pinus amandi) (8\% of all trees). The density of trees was about 40 - 60 plants per 100 $\mathrm{m}^{2}$. 
We studied small mammals in the disturbed forests at four different age classes (6 - 10, 11 - 15, 16 - 20, 31 40 years), and made a comparison with the protected forests in the same age classes. We used 3 replications of each age class in the protected and disturbed forests, resulting in 24 study sites in all.

\subsection{Estimation of Habitat Variables}

At each trapping site, we quantified 6 structural variables within randomly determined $5 \mathrm{~m} \times 5 \mathrm{~m}$ areas, with three replications. The 6 variables were: species richness, abundance and percent cover of grasses and shrubs respectively in the bottom layer of forests. Shrubs included all the woody perennial plants in the bottom layer of forests. Most of shrubs are lower than $1.5 \mathrm{~m}$, and few shrubs higher than $2 \mathrm{~m}$ were observed in these young forests. Grasses included the annual woody plants and herbaceous plants. It is reported that coarse woody debris (CWD) is also an important habitat factor for small mammals in forests (Loeb, 1999; McCay, 2000; Butts \& McComb, 2000; Carey \& Harrington, 2001). However, coarse woody debris was rare in these young forests, so it was not considered in this paper.

\subsection{Monitoring of Small Mammals}

Small mammals were sampled in June and July of 2004. Cage-traps $(10 \mathrm{~cm} \times 12 \mathrm{~cm} \times 18 \mathrm{~cm})$ baited with apple and oil-fried peanut were used to catch the mammals. At each site, we set 5 trap lines separated about $30 \mathrm{~m}$ from each other. Within each trap line, 20 trap-cages were each set $5 \mathrm{~m}$ apart for a total of 100 trap-cages per site. Trap-cages were examined and rebaited each morning for 3 consecutive days.

\subsection{Data Analysis}

The species richness and abundance of grasses and shrubs were defined as the number of species and the number of plants observed in each $5 \mathrm{~m} \times 5 \mathrm{~m}$ area. Species richness and abundance of small mammals were defined as the number of species and number of small mammals captured at each site. Dominance of small mammals in each community was defined by relative abundance.

The Shannon-Weaver diversity index, $H^{\prime}$ (Shannon \& Weaver, 1949),

$$
H^{\prime}=-\sum P_{i} \operatorname{Ln} P_{i}
$$

where $P_{i}$ is the proportion of the ith species in the total sample, was calculated to measure the diversity of small mammals. Comparison of data for abundance, species richness, diversity and habitat variables was analyzed using one-way analysis of variance (ANOVA). Stepwise linear regression was used to calculate the relationship between the habitat variables and small mammals. Before regression, the value of habitat variables were standardized.

\section{Results}

\subsection{Habitat Characteristics of the Forests Bottom Layer}

In the youngest forests ( 6 - 10 years), although the mean cover rate of shrubs in the protected sites was 1.20 times the one of the disturbed sites, there were no significant differences between them $(\mathrm{F}=1.500, \mathrm{df}=1.4, P=$ 0.288) (Figure 1). In the older forests, the percent cover of shrubs in the protected sites was significantly higher than the disturbed sites at the same age $(\mathrm{F}=36.300, \mathrm{df}=1.4, P=0.004,11-15$ years; $\mathrm{F}=248.909, \mathrm{df}=1.4, P<$ $0.001,16$ - 20 years; $\mathrm{F}=230.630, \mathrm{df}=1.4, P<0.001,31$ - 40 years). There was no significant difference in the shrub species richness in the youngest forest ( $6-10$ years) between the protect sites and disturbed sites $(\mathrm{F}=$ 4.000, $\mathrm{df}=1.4, P=0.116$ ). At the other three age classes, the species richness of shrubs in the protected sites was significantly higher than in the disturbed sites at the same age $(\mathrm{F}=28.800, \mathrm{df}=1.4, P=0.006,11$ - 15 years; $\mathrm{F}=132.250, \mathrm{df}=1.4, P<0.001,16-20$ years; $\mathrm{F}=8.450, \mathrm{df}=1.4, P=0.044,31-40$ years). The abundance of shrubs was significantly higher in the protected sites than the disturbed sites at the same age $(\mathrm{F}=22.011 \mathrm{df}=$ 1.4, $P=0.009,6$ - 10 years; $\mathrm{F}=11.635, \mathrm{df}=1.4, P=0.027,11-15$ years; $\mathrm{F}=246.791, \mathrm{df}=1.4, P<0.001,16$ 20 years; $\mathrm{F}=1003.227, \mathrm{df}=1.4, P<0.001,31-40$ years).

Contrary to the shrubs, percent cover and abundance of grasses in the disturbed forests were all significantly higher than those in the protected forests at the same age (Figure 1). The grass cover in the protected sites was 


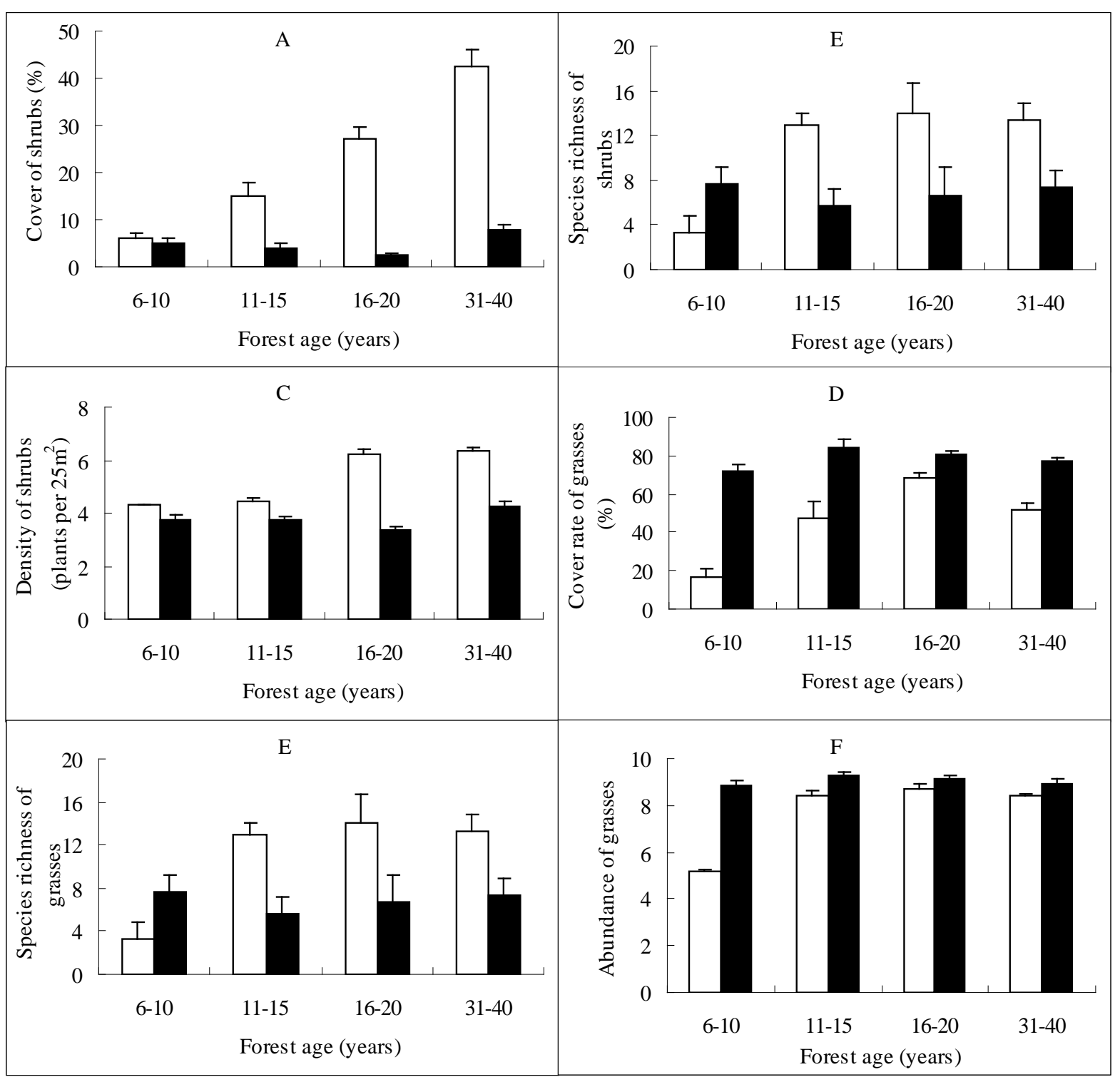

Figure 1. Value of structural variables in the disturbed and protected forests belonging to four different age classes. Mean value + SEM is given. White bar is protected forest; black bar is disturbed forest. (A)-(C) are the cover rate, species richness and abundance of shrubs respectively; (D)-(F) are the percent cover, species richness and abundance of grasses, respectively. The abundance of grasses is transformed by $\operatorname{Ln}(\mathrm{x})$, where $\mathrm{x}$ is abundance of grasses (plants per $25 \mathrm{~m}^{2}$ ).

$17 \%$ in the youngest forests (6 - 10 year), and was much lower than the disturbed sites of the same age, which was $71.67 \%(\mathrm{~F}=114.044, \mathrm{df}=1.4, P<0.001)$. The percent cover of grasses in the protected forests increased with age, and peaked at 16 - 20 years old. At $68.3 \%$, however this value was still significantly lower than the cover rate of grasses in the disturbed forests at all age classes. In the youngest forests ( $6-10$ year), species richness of grasses in the disturbed sites was higher than the protected sites $(\mathrm{F}=12.071 \mathrm{df}=1.4, P=0.025)$, while in the older forests $(11-40$ year), it was significantly lower than the protected site $(\mathrm{F}=48.400, \mathrm{df}=1.4, P=$ $0.002,11-15$ years; $\mathrm{F}=12.100, \mathrm{df}=1.4, P=0.025,16-20$ years; $\mathrm{F}=23.143, \mathrm{df}=1.4, P=0.009,31-40$ years).

\subsection{Small Mammal Community in Relation to Habitat Variables in Bottom Layer}

Abundance of small mammals in the protected forests and disturbed forests all increased with forest age, and the latter was two times more than the former at the same age $(\mathrm{F}=483.558, \mathrm{df}=1.4, P<0.001,6$ - 10 years; $\mathrm{F}=$ 
124.538, $\mathrm{df}=1.4, P<0.001,11-15$ years; $\mathrm{F}=159.998, \mathrm{df}=1.4, P<0.001,16-20$ years; $\mathrm{F}=212.457, \mathrm{df}=$ 1.4, $P<0.001,31$ - 40 years ) (Figure 2). Regression indicated that abundance of small mammals was affected by grasses in the bottom layer of forests, and increased with the percent cover of grasses, while density of small mammals decreased with the species richness of grasses (Table 1). There were no significant differences between species richness of small mammals in the protected and disturbed forests of the same age (Figure 2). The species richness was positively correlated to the species richness of shrubs (Table 1). Diversity index of the small mammals community in the protected forests was significantly higher than the disturbed forests of the same age $(\mathrm{F}=171.806, \mathrm{df}=1.4, P<0.001,6-10$ years; $\mathrm{F}=29.213, \mathrm{df}=1.4, P=0.006,11-15$ years; $\mathrm{F}=$ 103158, $\mathrm{df}=1.4, P=0.001,16-20$ years; $\mathrm{F}=26.523, \mathrm{df}=1.4, P=0.007,31-40$ years) (Figure 2). Diversity index of small mammals increased with the species richness of shrubs, and decreased with the percent cover of grasses in the bottom layer of forests (Table 1).

\subsection{Densities of Small Mammals in Relation to Habitat Variables in Bottom Layer}

Six species of small mammals, whose abundance constituted more than $3 \%$ of the total abundance of small mammals trapped in the forests, were analyzed to describe the abundance of mammals in relation to forest attributes (Table 1). A total of 276 Eothenomys miletus (Thomas), 90 Apodemus chevrieri (Milne-Edwards),

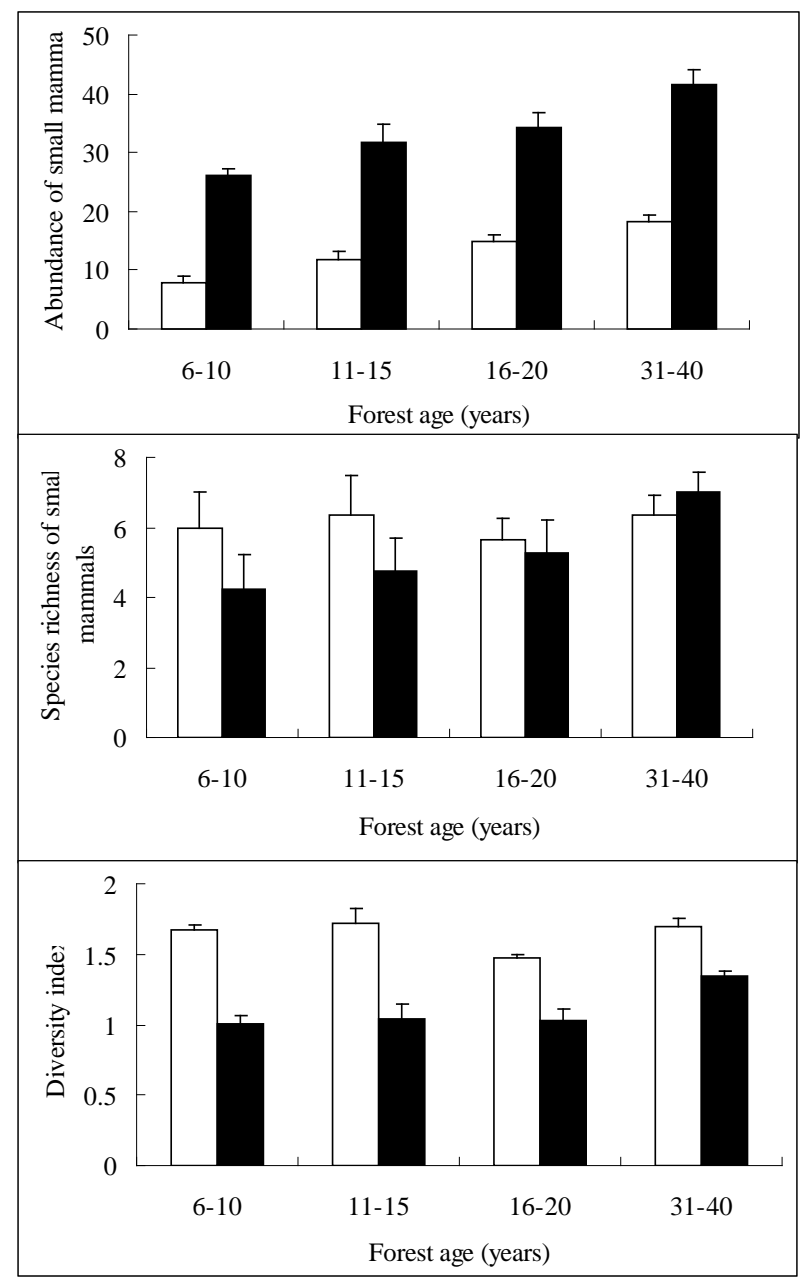

Figure 2. Abundance, species richness, and diversity index of small mammal communities in the protected forests and disturbed forests at the four age classes. Value + SEM is given. The white bar is protected forest; the black bar is disturbed forest. 
Table 1. Regression models to describe relationships between small mammal communities and habitat variables.

\begin{tabular}{cccccc}
\hline $\begin{array}{c}\text { Communities parameters } \\
\text { and species }\end{array}$ & Regression equation & $R$ & F-value & df & $P$ \\
\hline $\begin{array}{c}\text { Species richness } \\
\text { Diversity index }\end{array}$ & $\mathrm{Y}=5.667+0.549 \mathrm{X}_{1}$ & 0.456 & 5.782 & 1,22 & 0.025 \\
$\begin{array}{c}\text { Abundance of total small } \\
\text { mammals }\end{array}$ & $\mathrm{Y}=1.368+0.168 \mathrm{X}_{1}-0.195 \mathrm{X}_{5}$ & 0.900 & 44.574 & 2,21 & $<0.001$ \\
$\begin{array}{c}\text { E. miletus } \\
\text { A. chevrieri }\end{array}$ & $\mathrm{Y}=11.500-6.293 \mathrm{X}_{3}+7.418 \mathrm{X}_{5}$ & 0.826 & 22.549 & 22,21 & $<0.001$ \\
M. pahari & $\mathrm{Y}=3.750-1.251 \mathrm{X}_{3}+1.131 \mathrm{X}_{5}$ & 0.693 & 9.178 & 2,21 & 0.001 \\
T. belangeri & $\mathrm{Y}=14.792-1.624 \mathrm{X}_{3}+1.843 \mathrm{X}_{5}$ & 0.649 & 7.650 & 2,21 & 0.003 \\
D. pernyi & $\mathrm{Y}=1.250+1.459 \mathrm{X}_{1}$ & 0.800 & 39.089 & 1,22 & 0.001 \\
C. erythraeus & $\mathrm{Y}=1.792+1.999 \mathrm{X}_{3}$ & 0.914 & 112.285 & 1,22 & $<0.001$ \\
& $\mathrm{Y}=0.833+1.843 \mathrm{X}_{2}-0.670 \mathrm{X}_{4}$ & 0.828 & 22.983 & 2,21 & $<0.001$
\end{tabular}

Note: $\mathrm{X}_{1}, \mathrm{X}_{2}$ and $\mathrm{X}_{3}$ were species richness, cover rate and abundance of shrubs, respectively; $\mathrm{X}_{4}$ and $\mathrm{X}_{5}$ were species richness and percent grass cover, respectively.

Table 2. Dominance of small mammals in the protected forests and disturbed forests.

\begin{tabular}{|c|c|c|c|c|c|}
\hline \multirow{2}{*}{ Type of forests } & \multirow{2}{*}{ Species } & \multicolumn{4}{|c|}{ Age classes (years) } \\
\hline & & $6-10$ & $11-15$ & $16-20$ & $31-40$ \\
\hline \multirow[t]{6}{*}{ Protected forests } & E. miletus & 17.39 & 8.12 & 0.00 & 0.00 \\
\hline & A. chevrieri & 28.97 & 19.91 & 8.91 & 9.18 \\
\hline & M. pahari & 16.80 & 25.04 & 8.91 & 10.73 \\
\hline & T. belangeri & 8.47 & 12.22 & 35.97 & 27.14 \\
\hline & D.pernyi & 3.70 & 18.12 & 32.98 & 10.73 \\
\hline & C. erythraeus & 0.00 & 0.00 & 2.08 & 27.55 \\
\hline \multirow[t]{6}{*}{ Disturbed forests } & E. miletus & 61.90 & 61.60 & 63.08 & 49.84 \\
\hline & A. chevrieri & 10.40 & 14.96 & 14.75 & 15.85 \\
\hline & M. pahari & 21.95 & 16.04 & 15.77 & 17.24 \\
\hline & T. belangeri & 0.00 & 0.78 & 0.66 & 4.01 \\
\hline & D. pernyi & 0.00 & 0.00 & 0.00 & 1.42 \\
\hline & C. erythraeus & 0.00 & 0.00 & 0.00 & 3.07 \\
\hline
\end{tabular}

115 Mus pahari (Thomas), 30 Tupaia belangeri (Wagner), 43 Dremomys pernyi (Milne-Edwards), 20 Callosciurus erythraeus (Pallas) were captured in the study sites.

Small mammal species differed among the four age classes (6 - 10, 11 - 15, 16 - 20, 31 - 40 years) in the protected forests (Table 2). The two most dominant species were A. chevrieri and E. miletus in the youngest forest (6 - 10 years), M. pahari and A. chevrieri in the 11 - 15 years old forests, T. belangeri and D. pernyi in the 16 20 years old forests, $C$. erythraeus and T. belangeri in the oldest forests (31 - 40 years). The degree of dominance of the most dominant species was always under 30\% for each of the four age classes in the protected forests. In the disturbed forests, three small mammals were always the most dominant species at each of the four age classes. In particular, E. miletus was always the most dominant species scoring more than $45 \%$, with $M$. pahari and A. chevrieri being the second and third dominant species, respectively.

Regression indicated that the three most dominant species were positively influenced by the percent cover of grasses, and negatively affected by the abundance of shrubs, respectively (Table 1). The shrubs in the bottom 
layer were important to the species $T$. belangeri, $D$. pernyi and C. erythraeus. The abundance of $T$. belangeri was positively correlated with the species richness of shrubs, and the abundance of $D$. pernyi was positively affected by the abundance of shrubs. The abundance of $C$. erythraeus was positively influenced by the cover rate of shrubs, while negatively correlated with the species richness of grasses in the bottom layer (Table 1 ).

\section{Discussion}

Our results indicated that the structure and composition of the vegetation community in the bottom layer were simplified by the human disturbance. Compared with the protected forests, human disturbance significantly decreased species richness, cover rate (except the youngest forests) and abundance of shrubs, while it improved the cover rate and abundance of grasses, and simplified the species of grasses. In our observations, except for the youngest forests ( 6 - 10 years), the species richness of grasses in the protected forests was always significantly higher than the disturbed forests.

Animal species diversity driven by habitat heterogeneity is one of the cornerstones of ecology (e.g. Simpson, 1949). Tews et al. (2004) reviewed 85 publications on the relationship between habitat heterogeneity/diversity and animal species diversity for the period 1960-2003, and found most of these studies showed a positive correlation between habitat heterogeneity/diversity and animal species diversity. In our research, although no significant differences were observed in species richness of small mammals between the protected and disturbed forests at the same age, the diversity index of small mammals of the protected forests was always significantly higher than the disturbed forests. It was proposed that ground vegetation and structural heterogeneity should provide shelter and food for small mammals in forests (Adler, 1985; Batzli \& Lesieutre, 1995; Morris, 1997), and animal diversity was positively correlated to the plant species in the habitat (Haddad et al., 2001). Our results also indicated that the species richness and diversity of small mammals increased with the species richness of shrubs.

We also found that the total abundance of small mammals increased following the age of forests in the disturbed and protected forests, and the former was significantly higher than the later. The increased cover of grasses in the bottom layer was beneficial to the abundance of small mammals.

The succession of small mammals in the forests was widely researched, and most studies indicated that both species composition and abundance of small mammals changed with forest age (Kirkland, 1990; Ferreira \& Van Aarde, 1996; Ecke, 2002). Ferreira et al. (1996) found that the dominant species of small mammals was different in young rehabilitating forests of different ages and they indicated that this difference was attributed to species-specific habitat preferences, movement between areas and possible interactions among colonizing species. We found that there were obvious changes in small mammal communities with forest age in the protected forests. In the protected forests, the smaller body size and ground-dwelling small mammals (A. chevrieri, E. miletus and M. pahari) were the dominant species in the younger forests, the bigger body size and nonground-dwelling small mammals (T. belangeri, D. pernyi and C. erythraeus) became the dominant species as forests aged. However, the smaller ground-dwelling mammals (T. belangeri, D. pernyi and C. erythraeus) were always the dominant species at all ages in the disturbed forests. Adler (1985) suggested that habitat selection is an important determinant of structure in small mammal communities. Tews et al. (2004) also suggested different species groups were closely linked to keystone structures that determined animal species diversity by their presence. Models of species microhabitat associations can contribute to explicate differences in species succession and abundance. Regression indicated that the percent cover of grasses in the bottom layer was beneficial to the three smaller ground-dwelling mammals, while the abundance of shrubs was negative to these small mammals. Contrary to the ground-dwelling small mammals, the shrubs were beneficial to the three bigger body size and nonground-dwelling small mammals. We presume that the abundance of grass in the bottom layer might provide more food and shelter to smaller body and ground-dwelling small mammals, while shrubs could support shelters for bigger body size and nonground-dwelling small mammals.

Eothenomys and Apodemus often seriously damage young forests in China (Dong et al., 2003). Human disturbance in the bottom layer resulted in increased densities of $A$. chevrieri and E. miletus in the young restored forests, but also decreased their food resources in winter and early spring. This may result in increased damage to pine trees by the two rodents.

\section{Acknowledgements}

We are grateful for the effort that Prof. Marvin K. Harris (Texas A\&M University, America) made on our ma- 
nuscript. We thank the anonymous reviewers for helpful comments on draft of the manuscript. This work was funded by the Natural Science Fund of China (No. 81060139).

\section{Conflict of Interest}

None declared.

\section{References}

Adler, G. H. (1985). Habitat Selection and Species Interactions: An Experimental Analysis with Small Mammal Population. Oikos, 45, 380-390. http://dx.doi.org/10.2307/3565574

Batzli, G. O., \& Lesieutre, C. (1995). Community Organization of Arvicoline Rodents in Northern Alaska. Oikos, 72, 88-98. http://dx.doi.org/10.2307/3546042

Bowman, J. C., Sleep, D., Forbes, G. J., \& Edwards, M. (2000). The Association of Small Mammals with Coarse Woody Debris at Log and Stand Scales. Forest Ecology and Management, 129, 119-124. http://dx.doi.org/10.1016/S0378-1127(99)00152-8

Briggs, J. S., Vander Wall, S. B., \& Jenkins, S. H. (2009). Forest Rodents Provide Directed Dispersal of Jeffrey Pine Seeds. Ecology, 90, 675-687. http://dx.doi.org/10.1890/07-0542.1

Buckner, C. H. (1966). The Role of Vertebrate Predation in Biological Control of Forest Insects. Annual Review of Entomology, 11, 449-470. http://dx.doi.org/10.1146/annurev.en.11.010166.002313

Butts, S. R., \& McComb, W. C. (2000). Associations of Forest-Floor Vertebrates with Coarse Woody Debris in Managed Forests of Western Oregon. Journal of Wildlife Management, 64, 95-104. http://dx.doi.org/10.2307/3802978

Carey, A. B., \& Harrington, C. A. (2001). Small Mammals in Young Forests: Implications for Management for Sustainability. Forest Ecology and Management, 154, 289-309. http://dx.doi.org/10.1016/S0378-1127(00)00638-1

Carey, A. B., \& Johnson, M. L. (1995). Small Mammals in Managed, Naturally Young, and Old-Growth Forests. Ecological Applications, 5, 336-352. http://dx.doi.org/10.2307/1942026

Carey, A. B., Kershner, J., Biswell, B., \& DeToledo, L. D. (1999). Ecological Scale and Forest Development: Squirrels, Dietary Fungi, and Vascular Plants in Managed and Unmanaged Forests. Wildlife Monographs, 142, 3-71.

Costanza, R., Daly, H., Folke, C., Hawken, P., Holling, C. S., McMichael, A. J. et al. (2000). Managing Our Environmental Portfolio. Biosci, 50, 149-155. http://dx.doi.org/10.1641/0006-3568(2000)050[0149:MOEP]2.3.CO;2

Dong, X. B., You, D. K., Chang, G. L., \& Qiu, L. X. (2003). Control of the Damage of Forest Rodents in China. Forest Pest and Disease, 22, 36-40.

Dueser, R. D., \& Shugart Jr., H. H. (1978). Niche Pattern in a Forest-Floor Small-Mammal Fauna. Ecology, 60, $108-118$. http://dx.doi.org/10.2307/1936473

Dueser, R. D., \& Shugart Jr., H. H. (1979). Microhabitats in a Forest-Floor Small-Mammal Fauna. Ecology, 59, 89-98. http://dx.doi.org/10.2307/1936634

Ecke, F., Lögren, O., \& Sörlin, D. (2002). Population Dynamics of Small Mammals in Relation to Forest Age and Structural Habitat Factors in Northern Sweden. Journal of Applied Ecology, 39, 781-792.

http://dx.doi.org/10.1046/j.1365-2664.2002.00759.x

Ericson, L. (1977). The Influence of Voles and Lemmings on the Vegetation in a Coniferous Forest during a 4-Year Period in Northern Sweden. Sweden: Univeristy of Umeêa, 114 p.

Ferreira, S. M., \& VanAarde, R. J. (1996). Changes in Community Characteristics of Small Mammals in Rehabilitating Coastal Dune Forests in Northern KwaZulu/Natal. African Journal of Ecology, 34, 113-130. http://dx.doi.org/10.1111/j.1365-2028.1996.tb00606.x

Folke, C., Holling, C. S., \& Perrings, C. (1996). Biological Diversity, Ecosystems, and the Human Scale. Ecological Applications, 6, 1018-1024. http://dx.doi.org/10.2307/2269584

Gebczynska, Z. (1983). Feeding Habits. Acta Theriologica, 28, 40-49.

Haddad, N. M., Tilman, D., Haarstad, J., Ritchie, M., \& Knops, J. M. (2001). Contrasting Effects of Plant Richness and Composition on Insect Communities: A Field Experiment. The American Naturalist, 158, 17-35.

http://dx.doi.org/10.1086/320866

Hansson, L. (1988). Grazing Impact by Small Rodents in a Steep Cyclicity Gradient. Oikos, 51, 31-42. http://dx.doi.org/10.2307/3565804

Hörnfeldt, B., Carlsson, B. G., Löfgren, O., \& Eklund, U. (1990). Effects of Cyclic Food Supply on Breeding Performance in Tengmalm's Owl (Aegolius funereus). Canadian Journal of Zoology, 68, 522-530. http://dx.doi.org/10.1139/z90-077 
Kelt, D. A. (2000). Small Mammal Communities in Rainforest Fragments in Central Southern Chile. Biological Conservation, 92, 345-358. http://dx.doi.org/10.1016/S0006-3207(99)00107-X

Kirkland Jr., G. L. (1990). Patterns of Initial Small Mammal Community Change after Clearcutting of Temperate North American Forests. Oikos, 59, 313-320. http://dx.doi.org/10.2307/3545141

Krebs, C. J., \& Myers, J. H. (1974). Population Cycles in Small Mammals. Advances in Ecological Research, 8, $267-339$. http://dx.doi.org/10.1016/S0065-2504(08)60280-9

Liu, L. S., Liu, J. K., Luo, M. C., \& Wang, Y. X. (2003). Study on Existing Issues of National-Level Nature Reserves in Yunnan Province. Problems of Forestry Economics, 23, 146-152.

Loeb, S. C. (1999). Responses of Small Mammals to Coarse Woody Debris in a Southeastern Pine Forest. Journal of Mammalogy, 80, 460-471. http://dx.doi.org/10.2307/1383293

Manning, J. A., \& Edge, W. D. (2008). Small Mammal Responses to Fine Woody Debris and Forest Fuel Reduction in Southwest Oregon. Journal of Wildlife Management, 72, 625-632. http://dx.doi.org/10.2193/2005-508

McCay, T. S. (2000). Use of Woody Debris by Cotton Mice (Peromyscus gossypinus) in a Southeastern Pine Forest. Journal of Mammalogy, 81, 527-535. http://dx.doi.org/10.1644/1545-1542(2000)081<0527:UOWDBC>2.0.CO;2

McCay, T. S., \& Komoroski, M. J. (2004). Demographic Response of Shrews to Removal of Coarse Woody Debris in a Managed Pine Forest. Forest Ecology and Management, 189, 387-395. http://dx.doi.org/10.1016/j.foreco.2003.09.005

Men, X., Guo, X., Erdal, N. Y., Dong, W., \& Qian, T. (2006). Relationship between Small Mammal Community and Ecological Factors of Pine Plantations in Dali, Yunnan Province. Acta Zoologica Sinica, 52, 215-223.

Mengak, M. T., \& Guynn Jr., D. C. (2003). Small Mammal Microhabitat Use on Young Loblolly Pine Regeneration Areas. Forest Ecology and Management, 173, 309-317. http://dx.doi.org/10.1016/S0378-1127(02)00008-7

Mengak, M. T., Guynn Jr., D. C., \& VanLear, D. H. (1989). Ecological Implications of Loblolly Pine Regeneration for Small Mammal Communities. Forest Science, 35, 503-504.

Morris, D. W. (1997). Optimally Foraging Deer Mice in Prairie Mosaics: A Test of Habitat Theory and Absence of Landscape Effects. Oikos, 80, 31-42. http://dx.doi.org/10.2307/3546513

Niedziałlkowska, M., Kończak, J., Czarnomska, S., \& Jędrzejewska, B. (2010). Species Diversity and Abundance of Small Mammals in Relation to Forest Productivity in Northeast Poland. Ecoscience, 17, 109-119. http://dx.doi.org/10.2980/17-1-3310

Pearce, J., \& Venier, L. (2005). Small Mammals as Bioindicators of Sustainable Boreal Forest Management. Forest Ecology and Management, 208, 153-175. http://dx.doi.org/10.1016/j.foreco.2004.11.024

Plumpter, A. J. (2000). Monitoring Small Mammal Populations with Line Transect Techniques in African Forests. Journal of Applied Ecology, 37, 356-368. http://dx.doi.org/10.1046/j.1365-2664.2000.00499.x

Saitoh, T., \& Nakatsu, A. (1997). The Impact of Forestry on the Small Rodent Community of Hokkaido, Japan. Mammal Study, 22, 27-38. http://dx.doi.org/10.3106/mammalstudy.22.27

Shannon, C., \& Weaver, W. (1949). The Mathematical Theory of Communication. Urbana, IL: University of Illinois Press, $144 \mathrm{p}$.

Simpson, E. H. (1949). Measurement of Diversity. Nature, 163, 688.

Sullivan, T. P., \& Sullivan, D. S. (2001). Influence of Variable Retention Harvest on Forest Ecosystems. II. Diversity and Population Dynamics of Small Mammals. Journal of Applied Ecology, 38, 1234-1252.

Sullivan, T. P., Sullivan, D. S., \& Lindgren, P. M. F. (2000). Small Mammals and Stand Structure in Young Pine, Seed-Tree, and Old-Growth Forest, Southwest Canada. Ecological Applications, 10, 1367-1383. http://dx.doi.org/10.1890/1051-0761(2000)010[1367:SMASSI]2.0.CO;2

Tews, J., Brose, U., Grimm, V., Tielbörger, K., Wichmann, M. C., \& Schwager, M. (2004). Animal Species Diversity Driven by Habitat Heterogeneity/Diversity: The Importance of Keystone Structures. Journal of Biogeography, 31, 79-92. http://dx.doi.org/10.1046/j.0305-0270.2003.00994.x

Ure, D. C., \& Master, C. (1982). Mycophagy of Red-Backed Voles in Oregon and Washington. Canadian Journal of Zoology, 60, 3307-3315. http://dx.doi.org/10.1139/z82-419

Vander Wall, S. B. (1995). The Effects of Seed Value on the Caching Behavior of Yellow Pine Chipmunks. Oikos, 74, 533537. http://dx.doi.org/10.2307/3545999

Vander Wall, S. B. (1997). Dispersal of Singleleaf Pinon Pine (Pinus monophylla) by Seed-Caching Rodents. Journal of Mammalogy, 78, 181-191. http://dx.doi.org/10.2307/1382651

Wells, K., Corlett, R. T., Lakim, M. B., Kalko, E. K. V., \& Pfeiffer. M. (2009). Seed Consumption by Small Mammals from Borneo. Journal of Tropical Ecology, 25, 555-558. http://dx.doi.org/10.1017/S0266467409990058

Yahner, R. H. (1986). Microhabitat Use by Small Mammals in Even-Aged Forest Stands. American Midland Naturalist, 115, 174-180. http://dx.doi.org/10.2307/2425847 
Scientific Research Publishing (SCIRP) is one of the largest Open Access journal publishers. It is currently publishing more than 200 open access, online, peer-reviewed journals covering a wide range of academic disciplines. SCIRP serves the worldwide academic communities and contributes to the progress and application of science with its publication.

Other selected journals from SCIRP are listed as below. Submit your manuscript to us via either submit@scirp.org or Online Submission Portal.
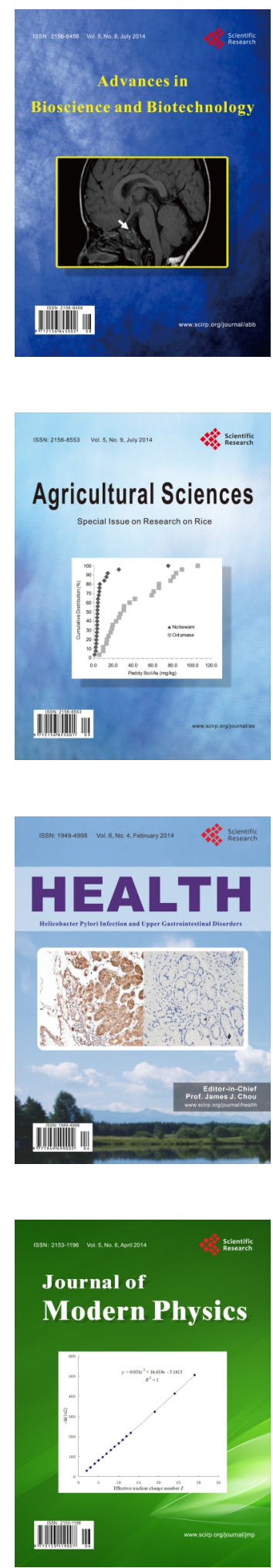
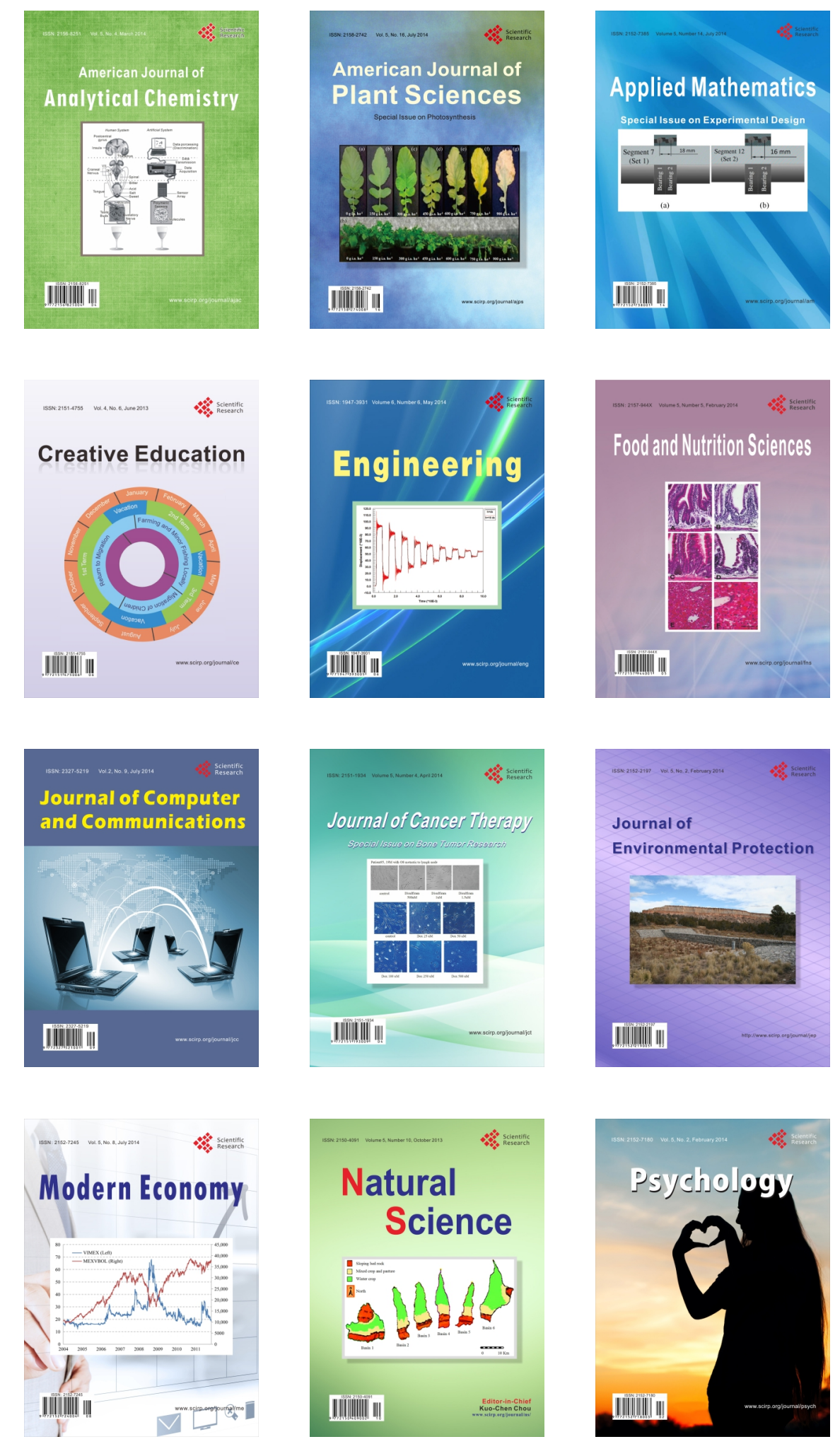